\section{THE GAS INDUSTRY}

W ILLIAMI MIURDOCH died one hundred years ago and, at the annual meeting of the Institution of Gas Engineers on June 6 last, his position as founder of the gas industry received grateful commemoration in a Murdoch Centenary Lecture delivered by Dr. E. F. Armstrong. The lecture was only to a small extent biographical, although points of interest are recorded bringing out clearly the all-round quality of the man as a born engineer "of admirable inventive power and common sense genius", to quote the tribute of Nasmyth. It was made the occasion for the preparation of a reasoned history of the gas industry in Great Britain in the small compass of sixty-seven pages, brief but packed with information concerning the highways and some of the byways on which the industry has travelled in time.

Although Murdoch is accorded his rightful place, proper acknowledgment is made of other founders of the industry, such as Samuel Clegg, whose "mark on its history is second only to that of Murdoch" and who became engineer of the Chartered Gas Company in 1813 and had "prac. tically single-handed to give a public service supply. Thus, when a few gas lamps were first installed on Westminster Bridge, the lamplighters refused to handle them so that he had to go round with his ladder and light them himself". Scepticism on the practicability and safety of public lighting with gas was very general and was shared even by men of the scientific calibre of Humphry Davy. Winsor also is not forgotten, a man of little technical knowledge but a fervent enthusiast, described as the "exploiter, propagandist and undaunted impresario of our Industry, to whom must be given the credit for the idea of widespread illumination from a single source".

The year 1839 was unusually eventful and, under the heading "A Century Ago", Dr. Armstrong sketches a background of contemporary happenings. In 1839 the first railway train left Euston on the first stage of the new London to Birmingham railway, the British Queen made the Atlantic crossing under steam alone, "Nicholas Nickleby" was published and people were reading Carlyle's "French Revolution", issued two years earlier, and the Sunday Times for January 13 reported that "On Thursday evening Hounslow was lighted up for the first time with gas supplied from the gasworks at Brentford. There are 18 lights." Both steam and gas, two great industrial users of coal, one for power and the other for lighting, had become more or less established by this time, and in an appendix Dr. Armstrong gives a list of ninety

\section{IN GREAT BRITAIN}

gas companies established by Act of Parliament up to 1839 .

A patent was granted in 1819 to David Gordon for compressing gas and supplying it in copper cylinders under a pressure of 30 atmospheres, and such 'portable gas' was used at the Royal Institu. tion until 1834, when it was replaced by coal-gas. "Historically", Dr. Armstrong points out, "the Portable Gas Company must always be associated with the discovery of benzene which Faraday separated in 1825 by distillation of the condensed oil gas liquor that collected in the vessels used by the Company."

The primary use of gas for more than a century was for lighting, and the story of the development of the apparatus in which it was burned has been well told by Dean Chandler. The invention of the incandescent mantle by Welsbach, first shown to the public in 1887, came at the right moment because "the electric bulb was introduced only a year or two carlier and started a new era of com. petition with gas-lighting". Dr. Armstrong quotes interesting figures for public lighting by gas in the area supplied by the South Metropolitan Gas Company. In 1899, with flat-flame burners, the candlepower per cubic foot of gas consumed per hour was 2.5 ; in 1902 , with upright incandescent burners, 14.0 ; and in 1938, when 70.6 miles of lighting by high-pressure lamps was included, the figure had risen to $43 \%$.

As the gas industry in Great Britain developed and monopoly of supply was granted to each company in its own area, the absence of competition and the technical possibility of producing a larger volume of leaner gas through the use of fireclay retorts (instead of iron) at a higher temperature brought into prominence the necessity for a rigid control of gas quality. For this purpose the City of London Gas Act of 1868 appointed a body of three competent and impartial persons known as the 'gas referees' to prescribe apparatus and methods to be used in the testing of gas. This arrangement continued until a few months ago when, as Dr. Armstrong regretfully remarks, "The disappearance of the Gas Referees, as the result of the Gas Undertakings Act of 1934, which has transferred their duties to the Board of 'Trade, has meant the loss of a contact with leaders in the scientific world to which the Gas Industry has attached great value." This is none the less true although, since the passing of the Gas Regulation Act of 1920 , calorific value has quite rightly taken the place of illuminating power as the criterion of quality throughout Great Britain. 
It was recognized early in the history of the gas industry that the presence of sulphur compounds in gas was very objectionable and Clegg tried as early as 1805 the device of putting lime into the tank of the gas-holder for purification. Dr. Armstrong points out that eleven different processes were in operation in the gas works of the Metropolis in 1856-57. The complete removal of sulphuretted hydrogen by iron oxide, revivified by air, has become standard practice, but the residual sulphur compounds, amounting usually to some $20-30$ grains per $100 \mathrm{c}$. ft. still provide an incentive to research, although oil-washing for benzole and the CarpenterEvans catalytic process have both been applied successfully to. lower this figure.

The usefulness of gas as a fuel for heating purposes and its virtues were "extolled by the in. defatigable Winsor". Alfred King invented a gascooking-stove so early as 1830, and in 1872 the Salisbury Gas Company commenced hiring cookers to consumers. The earliest attempts were simply solid fuel ovens with gas burners inserted, and Dr. Armstrong traces the development to the cooker of to-day with enamelled finish, thermostatic control, safety-taps, quick-boiling burners and other useful adjuncts. By 1850 there were a number of gas fires in use, these consisting merely of lumps of pumice or other incombustible matter in a coal-grate with a gas-burner below. It was not until between 1904 and 1908 that the gas-fire radiant was introduced, and a new impetus was given to efficiency of design by the experimental study of the gas-fire by the newly formed Joint Research Committee of the Institution of Gas Engineers and the University of Leeds. Modern design is directed to high radiant efficiency combined with a distribution of heat making for the maximum of comfort. Ventilation too has been studied in detail. The rise in radiant efficiency is given by Dr. Armstrong as from 29 per cent on the gross calorific value in 1909 to 45 per cent in 1939 on the same basis.

It is not possible to make more than a mention of many other matters which are included in the lecture, some gratifying curiosity and others a deeper interest ; for example, the possibilities of a greatly increased load for industrial heating offer an excellent example, and the whole range of secondary products, such as coke, tar and ammoniacal liquor. The modification of the retort from iron to fire-clay, horizontal to vertical, intermittent to continuous, and the whole subject of water-gas must be left, as well as an interesting page on co-partnership and a synopsis of gas legislation. There is, too, a suggestive final chapter entitled "The Present and Future of Gas", in. dicating possible lines of advance and insisting on the gas industry's taking a pride in attracting the best men into its ranks both as whole-time workers and as advisers.
JoHN W. СовB.

\section{CERCOSPORA LEAF SPOT DISEASE OF BANANAS}

\section{By Dr. C. W. Wardiaw, Imperial College of Tropical Agriculture, Trinidad}

$\mathrm{T}^{\mathrm{H}}$

HOUGH widely distributed in the Indo. Malayan and Australian regions and known to mycologists since 1902 , the leaf spot disease of bananas caused by Cercospora musa Zimm. (also known as Sigatoka disease) was not recorded in the western tropics until $1934^{1}$. It is not known precisely how or when this malady was introduced into the Caribbean region, or whether its spread took place from one or several foci of infection; but during the brief period of two to three years from its first recognition in Trinidad it had appeared with epidemic intensity in many of the islands and on the mainland of Central and South America, and by its destructive effects on plantations showed itself to be a disease of first-class economic importance.

Briefly, the disease manifests itself as a profuse spotting of leaves; later, the tissue around the spots begins to die rapidly and large, coalescing dead patches appear, so that in severe infections the leaf may be more or less completely destroyed (Figs. 1 and 2). Bunches on affected plants show slow or arrested growth and behave abnormally during development and subsequent ripening. Where the economic situation permits, the disease is being fought by dusting and spraying with various copper-containing fungicides.

\section{SPREAd AND InTENSIFICATION}

Information on the spread and intensification of a disease from an initial infection to the stage where it has assumed epidemic proportions is not always available to the investigator. In Trinidad, however, it has been possible to follow the progress of Cercospora leaf disease through its several phases. The disease was first observed in the Maqueripe district in north-west Trinidad in a small, new plantation of Giant Governor bananas, the planting material for which 